\title{
EKSTRAK AIR DAUN SIRIH (Piper betle Linn) SEBAGAI ANTIOKSIDAN ALAMI PADA PENGOLAHAN IKAN PATIN (Pangasius hypophthalmus) ASIN KERING
}

\section{Water Extract of Betel Leaf (Piper betle Linn) as Natural Antioxidant on the Processing of Dried Salted Catfish (Pangasius hypophthalmus)}

\author{
Farida Ariyani ${ }^{\star \star}$, Irianti Amin $^{2}$, dan Dedi Fardiaz ${ }^{2}$ \\ ${ }^{1}$ Balai Besar Penelitian dan Pengembangan Pengolahan Produk dan Bioteknologi Kelautan dan Perikanan, \\ Jl. K.S. Tubun Petamburan VI, Jakarta Pusat, Indonesia \\ ${ }^{2}$ Program Studi IImu Pangan IPB, Bogor, Indonesia \\ * Korespondensi Penulis: idapoernomo@yahoo.co.id
}

Diterima: 4 Februari 2015; Disetujui: 13 April 2015

\begin{abstract}
ABSTRAK
Kajian peran ekstrak air daun sirih sebagai antioksidan alami pada proses pengolahan ikan patin asin kering telah dilakukan. Penambahan ekstrak air daun sirih pada berbagai konsentrasi $(0,4,5,6,7 \% \mathrm{~b} / \mathrm{v})$ dilakukan pada saat perendaman patin segar dalam larutan garam jenuh selama 48 jam. Selanjutnya patin asin hasil penggaraman dikeringkan di bawah sinar matahari selama 4-5 hari. Pengamatan aktivitas antioksidan ekstrak air daun sirih dilakukan dengan metode 2,2-diphenyl-1-picrylhydrazyl (DPPH) yang dibandingkan dengan Buthylated Hydroxytoluene (BHT) sebagai kontrol positif, sedangkan pengamatan efektivitas ekstrak air daun sirih sebagai antioksidan patin asin dilakukan melalui analisis parameter oksidasi yakni angka TBA, angka anisidin dan produk berfluoresen serta karakteristik sensori (warna, bau, dan rasa). Hasil kajian menunjukkan bahwa ekstrak air daun sirih memiliki aktivitas antioksidan lebih tinggi dibandingkan BHT. Penambahan ekstrak air daun sirih dengan konsentrasi 4-7\% (b/v) selama penggaraman dalam proses pengolahan patin asin mampu menghambat proses oksidasi lemak patin asin dan patin asin kering yang tercermin dari rendahnya angka TBA, angka anisidin dan produk berfluoresen dibanding kontrol. Perlakuan terpilih dari penelitian ini adalah kelompok perlakuan penambahan ekstrak daun sirih $4 \%$ yang menghasilkan patin asin kering dengan angka TBA 6,42 $\mu \mathrm{Mol} \mathrm{MDA} / \mathrm{kg}$ (kontrol 15,10 $\mu \mathrm{Mol} \mathrm{MDA} / \mathrm{kg}$ ), angka anisidin 3,41 $\mu \mathrm{Mol} / \mathrm{g}$ minyak (kontrol 6,87 $\mu \mathrm{Mol} / \mathrm{g}$ minyak), dan produk berfluoresen 0,091 $\mu \mathrm{g} / \mathrm{g}$ ikan (kontrol 0,219 $\mu \mathrm{g} / \mathrm{g}$ ikan). Karakteristik sensori patin asin dengan perlakuan terpilih berwarna coklat muda, berbau tidak tengik, dan berasa sedikit getir.
\end{abstract}

KATA KUNCl: $\quad$ ekstrak sirih hijau, antioksidan, patin asin kering

\section{ABSTRACT}

Study on the role of water extract of betel leaf as antioxidant on the processing of dried salted catfish has been conducted. The addition of water extract of betel leaf with various concentration of $0,4,5,6,7 \% \mathrm{w} / \mathrm{v}$ was carried out during salting process i.e., during immersing of fresh catfish in saturated brine for $48 \mathrm{~h}$. Subsequently, salted catfish was sundried for 4-5 days. Observation on antioxidant activity of water extract of betel leaf was performed by 2,2-diphenyl-1-picrylhydrazyl (DPPH) method compared to Buthylated Hydroxytoluene (BHT) as positive control, while observation on the antioxidant effectiveness of water extract of betel leaf for dried salted catfish was conducted by analyzing oxidative parameters including TBA value, anisidine value and fluorescent products as well as sensory characteristics (colour, aroma and taste). Results showed that water extract of betel leaf had higher antioxidant activity compared to BHT. The addition of water extract of betel leaf at concentration of 4-7\% (W/v) during salting process enabled to inhibit fat oxidation of both salted catfish and dried salted catfish, reflected by lower TBA value, anisidine value and fluorescent product compared to control. The best treatment of this experiment was the addition of $4 \%$ water extract of betel leaf, producing dried salted catfish with TBA value of $6.42 \mu \mathrm{Mol}$ MDA/kg (control $15.10 \mu \mathrm{Mol} \mathrm{MDA} / \mathrm{kg}$ ), anisidin value of $3.41 \mu \mathrm{Mol} / \mathrm{g}$ oil (control $6.87 \mu \mathrm{Mol} / \mathrm{g}$ oil), and fluorescent products of $0.091 \mu \mathrm{g} / \mathrm{g}$ fish (control $0.219 \mu \mathrm{g} / \mathrm{g}$ fish). Sensory characteristics of the dried salted catfish was light brown in colour, not rancid in odour and slightly pungent in taste.

KEYWORDS: $\quad$ piper betel extract, antioxidant, dried salted catfish 


\section{PENDAHULUAN}

Ikan asin merupakan salah satu produk olahan tradisional di Indonesia yang banyak disukai masyarakat yang tercermin dari angka produksi ikan asin di Indonesia yang cukup tinggi dibandingkan produk olahan tradisional lain atau bahkan produk perikanan olahan lain. Berdasarkan data produksi komoditas perikanan Indonesia (Ditjen Perikanan Tangkap, 2013), produk ikan asin mencapai 424.408 ton atau $35,09 \%$ dari total produk perikanan olahan dan menduduki peringkat ke-2 setelah produk perikanan beku. Apabila dibandingkan dengan jumlah produk olahan tradisional lain, ikan asin menduduki peringkat pertama dengan persentase sebesar $61,60 \%$, diikuti produk asap $15,69 \%$ dan pindang $14,69 \%$. Pengolahan ikan asin kebanyakan dilakukan secara tradisional melalui penggaraman dan pengeringan. Pengeringan yang biasa dilakukan secara terbuka di bawah sinar matahari berpotensi menimbulkan kerusakan karena proses oksidasi. Kandungan minyak pada produk perikanan dengan proporsi asam lemak tidak jenuh yang cukup tinggi berkontribusi terhadap kerusakan karena proses oksidasi.

Ikan patin merupakan ikan hasil budidaya yang berdaging tebal dan berkadar lemak tinggi (Hwang et al., 2004; Ariyani et al., 2008). Selain diproses untuk diambil dagingnya sebagai fillet, ikan patin juga berpeluang untuk diolah menjadi ikan asin jambal yang biasanya diolah dari ikan manyung sebagai ikan hasil tangkapan. Kandungan lemak dan asam lemak tidak jenuh yang tinggi pada ikan patin (Hwang et al., 2004; Widjaja et al., 2009a) berpotensi menimbulkan kerusakan yang bersifat oksidatif. Penambahan bahan sebagai antioksidan selama proses pengolahan merupakan salah satu alternatif yang dapat digunakan untuk menekan kerusakan karena proses oksidasi.

Daun sirih (Piper betle Linn) merupakan salah satu tanaman yang mempunyai aktivitas sebagai antioksidan (Lim \& Mohamed,1999; Choundhary \& Kale, 2002; Dasgupta \& Bratati, 2004; Arambewela et al., 2006a). Ekstrak daun sirih memiliki aktivitas antioksidan dan dapat menurunkan tingkat ketengikan pada minyak kelapa dan minyak sawit, dapat menekan proses oksidasi pada kentang goreng (Arambewela et al., 2006b), saus sambal/chilli bo (Wendy Voon et al., 2014) dan ikan olahan selama penyimpanan (Legowo et al., 2002; Ariyani et al., 2008; Sanger, 2010). Namun, peran ekstrak daun sirih dalam menekan laju oksidasi selama proses pengolahan patin asin belum dieksplorasi. Pada penelitian ini dilakukan observasi terhadap kerusakan karena oksidasi selama proses pembuatan patin asin dengan penambahan ekstrak daun sirih.

\section{BAHAN DAN METODE}

\section{Bahan}

Bahan yang digunakan pada penelitian ini adalah ikan patin (Pangasius hypophthalmus) dengan ukuran 650-700 g/ekor yang diperoleh dari pembudidaya ikan patin di Darmaga, Bogor, garam krosok ukuran sedang yang diperoleh dari Pasar Palmerah, dan daun sirih hijau (Piper betle Linn) segar yang merupakan daun ke 4-5 dihitung dari pucuk daun yang diperoleh dari Balai Penelitian Tanaman Rempah dan Obat di Bogor.

\section{Metode}

\section{Preparasi ekstrak daun sirih}

Sebelum dilakukan ekstraksi, daun sirih terlebih dahulu dicuci untuk menghilangkan kotoran yang masih menempel, ditiriskan dan dikeringanginkan. Daun sirih yang telah bersih kemudian dimasukkan ke dalam air mendidih dengan perbandingan daun sirih : air = 1:4 (b/v) dan dibiarkan mendidih selama 4 jam (Arambewela et al., 2006b). Setelah selesai perebusan, ekstrak kemudian disaring menggunakan kain nilon berukuran 30 mesh untuk memisahkan filtrat dari ampasnya. Volume filtrat kemudian dikembalikan ke volume awal $(4 \mathrm{~L})$ dengan menambahkan air mendidih pada filtrat sehingga diperoleh ekstrak kasar. Ekstrak kasar ini kemudian disimpan dalam jerigen berwarna gelap dan disimpan pada suhu $4{ }^{\circ} \mathrm{C}$ sampai siap digunakan.

\section{Aplikasi ekstrak daun sirih untuk menghambat oksidasi lemak pada patin asin}

Pembuatan patin asin dimulai dengan penyiangan bahan baku (pembuangan kepala dan isi perut), pencucian, penirisan, penyimpanan dalam wadah tertutup selama 6 jam (untuk mendapatkan tekstur patin asin yang empuk), penggaraman (dengan perendaman ikan patin dalam campuran larutan garam dan ekstrak daun sirih selama 48 jam), pencucian, pembelahan dari arah punggung ke kepala sehingga berbentuk butterfly, dan pengeringan di bawah sinar matahari selama 4-5 hari (Nasran et al., 1995; Haryati, 2006) atau sampai kadar air patin asin kering berkisar 21-23\%.

Pada proses penggaraman, konsentrasi larutan garam adalah $30 \%$ yaitu 30 bagian garam dalam 100 bagian pelarut, di mana pelarut terdiri dari larutan ekstrak daun sirih, dan air. Penentuan konsentrasi ekstrak daun sirih dalam penelitian ini didasarkan pada hasil penelitian pendahuluan yang menunjukkan bahwa konsentrasi terkecil ekstrak daun sirih yang masih 
memiliki aktivitas sebagai antioksidan adalah konsentrasi 6\% (Heruwati et al., 2007), sehingga konsentrasi ekstrak daun sirih yang dipilih sebagai perlakuan pada penelitian ini adalah $4,5,6$, dan 7 serta $0 \%$ (kontrol). Perbandingan antara ikan dan larutan yang digunakan untuk perendaman adalah 1:2 (b/v). Percobaan dilakukan dengan 3 kali ulangan.

\section{Pengamatan}

Pengujian terhadap aktivitas antioksidan ekstrak air daun sirih dilakukan dengan metode 2,2-diphenyl1-picrylhydrazyl (DPPH) menurut Dasgupta \& Bratati (2004) yang didasarkan pada pengukuran konsentrasi radikal bebas DPPH. Sebanyak 0,1 ml ekstrak air daun sirih, ditambah $3 \mathrm{ml}$ larutan DPPH 0,004\% dalam metanol dan dikocok. Setelah 30 menit pada suhu ruang, absorban diukur pada panjang gelombang 517 $\mathrm{nm}$. Sebagai blanko digunakan metanol dengan pengerjaan yang sama. BHT digunakan sebagai kontrol positif.

Pengamatan secara kimiawi terhadap patin asin dan patin asin kering yang dihasilkan dilakukan untuk parameter TBARS (Ramanathan \& Das, 1992), angka anisidin (AOCS, 1997) dan produk berfluorosen (Fletcher et al., 1973; Lubis 1989). Ekstraksi minyak untuk analisis angka anisidin dan produk berfluoresen dilakukan menurut Bligh \& Dyer (1959), sedangkan penentuan lemak total dilakukan menurut SNI 012354.3-2006 (BSN, 2006).

Pengamatan secara organoleptik dengan uji pembeda dilakukan menurut Meilgaard et al. (1999) terhadap atribut warna dan bau untuk patin asin kering mentah dan atribut bau serta rasa untuk patin asin kering matang. Pada uji pembedaan atribut warna pada patin asin kering mentah, digunakan lembar penilaian dengan rentang skor 1-5 dengan kriteria 1=coklat kehitaman, 2=coklat tua, 3=coklat muda, 4=kuning kecoklatan, dan 5=kuning muda (Lampiran 1), sedangkan kriteria atribut bau adalah 1=sangat tengik, 2=tengik, 3=agak tengik, 4=tidak tengik, dan $5=$ spesifik ikan asin (Lampiran 2). Pengujian pembedaan bau patin asin kering matang menggunakan kriteria yang sama dengan kriteria penilaian patin asin kering mentah, sedangkan penilaian rasa patin asin kering matang dilakukan menggunakan lembar penilaian dengan skor $1-5$, yang dideskripsikan 1 = sangat getir, 2 = getir, 3 = sedikit getir, 4 = tidak getir, 5 = spesifik ikan asin (Lampiran 3).

Rancangan percobaan yang digunakan pada penelitian ini adalah Rancangan Acak Lengkap Faktorial dengan 2 perlakuan yaitu jenis olahan (asin dan asin kering) dan konsentrasi ekstrak air sirih (4 konsentrasi) dengan 3 ulangan.

\section{HASIL DAN BAHASAN}

\section{Aktivitas Ekstrak Air Sirih}

Pengukuran aktivitas ekstrak air daun sirih sebagai antioksidan didasarkan pada \% penghambatan DPPH dan dinyatakan dengan $\mathrm{IC}_{50}$ yaitu ekstrak yang dapat menghambat 50\% radikal DPPH (Dasgupta \& Bratati (2004). Pada penelitian ini, pengukuran aktivitas ekstrak air daun sirih dibandingkan dengan aktivitas antioksidan sintetis Butylated Hydroxyl toluene (BHT).

Berdasarkan Tabel 1, terlihat bahwa angka $I_{50}$ ekstrak air daun sirih sebesar $134 \mu \mathrm{g} / \mathrm{ml}$ lebih kecil dibanding IC ${ }_{50}$ BHT sebesar $197 \mu \mathrm{g} / \mathrm{ml}$. Hal ini berarti bahwa aktivitas antioksidan ekstrak daun sirih pada penelitian ini masih lebih baik dibandingkan $\mathrm{BHT}$.

Hasil penelitian ini sejalan dengan Sugiastuti (2002) dan Arambewela et al. (2006b) yang menyatakan bahwa ekstrak ethanol daun sirih mempunyai aktivitas antioksidan yang lebih besar dibandingkan dengan $\mathrm{BHT}$, sementara hasil observasi Alam et al. (2012) menunjukkan bahwa ekstrak methanol daun sirih hijau memiliki aktivitas antioksidan $\left(\mathrm{IC}_{50} 16,33 \mu \mathrm{g} / \mathrm{ml}\right)$ yang hampir mendekati aktivitas antioksidan asam askorbat $\left(\mathrm{IC}_{50} 12,10 \mu \mathrm{g} / \mathrm{ml}\right)$. Hasil pengamatan beberapa peneliti menunjukkan bahwa pada umumnya aktivitas antioksidan yang tinggi dari daun sirih hijau terletak pada ekstrak semi polar antara lain ethyl acetat, ethanol, maupun methanol (Arambewela et al., 2011; Abrahim et al., 2012; Shah et al., 2013; Jaiswal et al., 2014). Namun demikian, beberapa peneliti menyatakan bahwa ekstrak air (polar) daun sirih hijau juga mempunyai potensi sebagai antioksidan (Dasgupta \& Bratati, 2004; Pin, et al., 2010; Arawwawala et al., 2011). Menurut Dasgupta \& Bratati

Tabel 1. Aktivitas antioksidan ekstrak air daun sirih dan BHT

Table 1. Antioxidant activity of water extract of betel leaf and BHT

\begin{tabular}{lc}
\hline \multicolumn{1}{c}{ Sampel/Samples } & IC $_{\mathbf{5 0}}(\boldsymbol{\mu g} / \mathrm{mI})$ \\
\hline Ekstrak air daun sirih/Water extract of betel leaf & 134 \\
BHT & 197 \\
\hline
\end{tabular}


(2004), aktivitas antioksidan ekstrak air sirih bervariasi (63-272 $\mu \mathrm{g} / \mathrm{L}$ ) tergantung pada jenis sirih. Besarnya potensi ekstrak air sebagai antioksidan diduga karena adanya komponen hydroxychavicol sebagai komponen mayor pada ekstrak air daun sirih (Pin et al., 2010), dan dilaporkan bahwa hydroxychavicol berkontribusi dalam menghambat proses oksidasi (Rathee et al., 2006).

\section{Angka TBA}

Perubahan angka TBA hasil penelitian ini disajikan pada Gambar 1. Pada patin segar, angka TBA masih rendah untuk semua perlakuan termasuk kontrol, namun pada patin asin terlihat bahwa angka TBA meningkat cukup signifikan pada kontrol maupun pada patin asin dengan perlakuan perendaman dalam ekstrak air sirih dan peningkatan paling tinggi ditunjukkan oleh patin asin kontrol yang hanya direndam larutan garam tanpa penambahan ekstrak air sirih. Ini mengindikasikan bahwa perlakuan perendaman dalam larutan garam meningkatkan proses oksidasi. O'Sullivan et al. (2004) mengamati adanya peningkatan kandungan malonaldehid secara signifikan pada nugget ayam asin dibanding nugget ayam tanpa penambahan garam. Hasil penelitian Ceballos (2012) juga menunjukkan bahwa pengasinan pada ikan cod telah meningkatkan angka TBARS menjadi 2 kali dibandingkan dengan angka TBARS pada bahan baku, dari semula 3,79 $\mu \mathrm{mol} / \mathrm{g}$ menjadi
$6,15 \mu \mathrm{mol} / \mathrm{g}$. Percepatan proses oksidasi oleh adanya garam kemungkinan diduga disebabkan adanya penurunan aktivitas enzim antioksidan seperti katalase, glutatione peroxidase, superoxide dismutase dan stimulasi oksidasi lipid melalui aktivasi Fe oleh ion $\mathrm{Cl}$, substitusi molekul Fe dari struktur mioglobin oleh ion Na yang berakibat pada tersedianya Fe bebas untuk mengkatilis oksidasi (Hernandez et al., 2002 dalam Devatkal et al., 2011; Zanardi, 2014).

Setelah proses pengeringan, terjadi kenaikan angka TBARS pada patin asin kontrol yang disebabkan adanya proses oksidasi selama pengeringan di bawah sinar matahari yang melibatkan ketersediaan oksigen dari atmosfir di sekitar tempat penjemuran ikan dan paparan terhadap sinar ultra violet. Dinyatakan oleh Ceballos (2012) bahwa ikan cod yang dikeringkan 2 hari teroksidasi lebih tinggi dari ikan cod yang dikeringkan 1 hari yang tercermin dari nilai carbonil sebagai komponen hasil oksidasi yang lebih tinggi pada pengeringan 2 hari. Rao \& Bandyopadhyay (1983) juga menyatakan bahwa penggaraman dan pengeringan dengan sinar matahari menyebabkan oksidasi lemak pada mackerel.

Hasil penelitian ini mendukung pernyataan Pokorny et al. (2001) bahwa oksidasi juga dapat terjadi secara spontan karena adanya oksigen di atmosfer dan adanya enzim lipoksigenase dalam bahan pangan serta ion logam yang akan mempercepat proses oksidasi tersebut. Ditinjau dari besaran angka TBARS

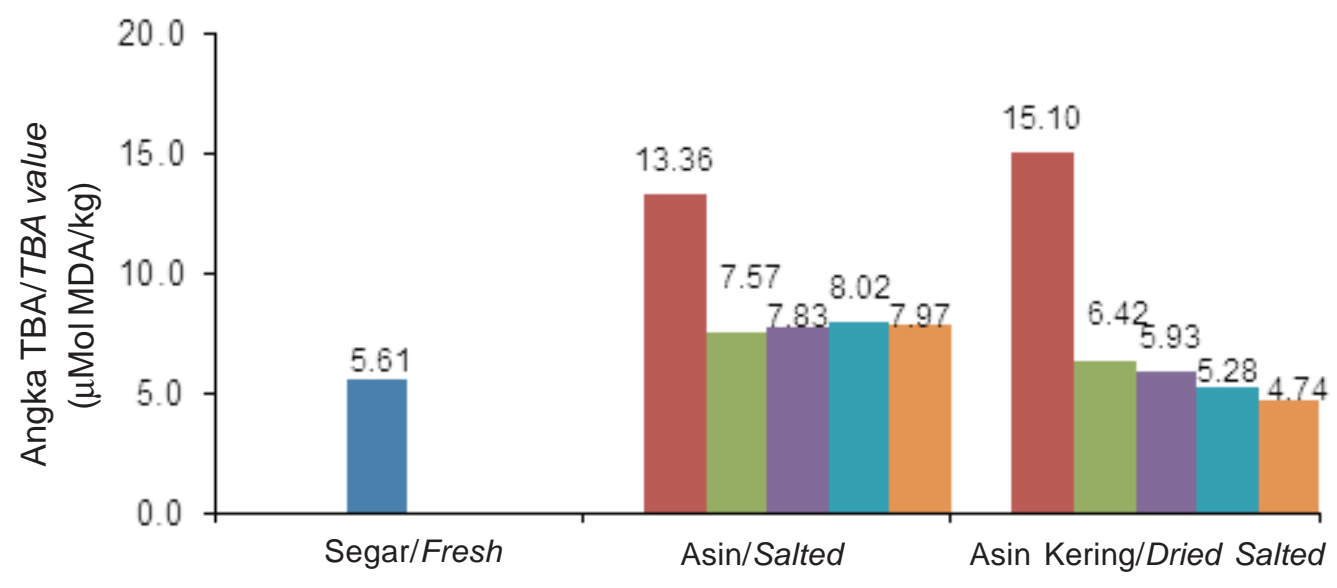

Jenis produk patin/Kind of patin products

- Kontrol/Control

Ekstrak sirih/Betel extract : 5.0\%

Ekstrak sirih/Betel extract : $7.0 \%$
Ekstrak sirih/Betel extract : 4.0\%

Ekstrak sirih/Betel extract : $6.0 \%$

Gambar 1. Angka TBA patin segar, patin asin, dan patin asin kering pada berbagai perlakuan penambahan ekstrak air daun sirih.

Figure 1. TBA Value of fresh, salted and dried salted catfish with addition of various betel leaf water extract. 
pada penelitian ini, patin asin dan patin asin kering dengan perlakuan ekstrak daun sirih memiliki angka TBARS yang jauh lebih rendah dibanding kontrol. Hal ini mencerminkan bahwa ekstrak daun sirih dapat menekan proses terjadinya degradasi lipid yang menghasilkan malonaldehid yang akan bereaksi dengan TBA sehingga berakibat pada rendahnya angka TBARS pada patin asin dengan perlakuan ekstrak daun sirih.

Berdasarkan pada ketentuan bahwa ikan dikatakan tengik apabila mempunyai angka TBARS lebih besar dari $10 \mu \mathrm{Mol} / \mathrm{kg}$ daging (Ke \& Ackman, 1976), maka patin asin maupun patin asin kering kontrol telah melebihi batas tersebut yang berarti telah tengik, sementara patin asin dan patin asin kering dengan perlakuan ekstrak daun sirih memiliki agka TBARS di bawah $10 \mu \mathrm{Mol} / \mathrm{kg}$ daging (Gambar 1) dan belum tengik. Hal ini seiring dengan hasil analisis sensori yang menunjukkan bahwa patin asin kering kontrol memiliki nilai bau antara agak tengik dan tengik, sementara patin asin kering dengan perlakuan ekstrak daun sirih memiliki nilai bau antara tidak tengik dan agak tengik. Intensitas ketengikan patin asin kering semakin tinggi dengan semakin rendahnya konsentrasi ekstrak daun sirih (Gambar 6). Dengan demikian penambahan ekstrak daun sirih selama penggaraman mampu menekan perkembangan proses oksidasi yang pada akhirnya menekan ketengikan, dan semakin tinggi konsentrasi ekstrak daun sirih dalam larutan garam, semakin besar kemampuannya dalam menghambat perkembangan oksidasi.

\section{Angka Anisidin}

Angka anisidin merupakan parameter untuk pengukuran produk oksidasi sekunder yang bersifat non volatil yakni aldehid (terutama 2-alkenal dan 2,4dienal) dalam minyak yang akan bereaksi dengan panisidin membentuk kromogen yang menyerap pada panjang gelombang $350 \mathrm{~nm}$ (Pokorny et al., 2001).

Hasil analisis terhadap angka anisidin menunjukkan bahwa angka anisidin patin asin dan patin asin kering pada kelompok kontrol lebih tinggi secara nyata dibandingkan kelompok dengan perlakuan ekstrak air daun sirih (Gambar 2).

Proses penggaraman telah meningkatkan angka anisidin karena diketahui bahwa garam merupakan salah satu senyawa yang mempercepat proses oksidasi (Zanardi, 2014). Domiszewski et al. (2011) menyatakan bahwa penambahan garam pada perebusan ikan patin meningkatkan angka anisidin menjadi 2 kali lipat dibanding ikan patin tanpa penambahan garam. Kolodziejska et al. (2004) juga menyatakan bahwa pemberian garam pada ikan asap menyebabkan peningkatan angka anisidin. Perlakuan pengeringan secara nyata telah menaikkan angka anisidin dibandingkan perlakuan garam tanpa

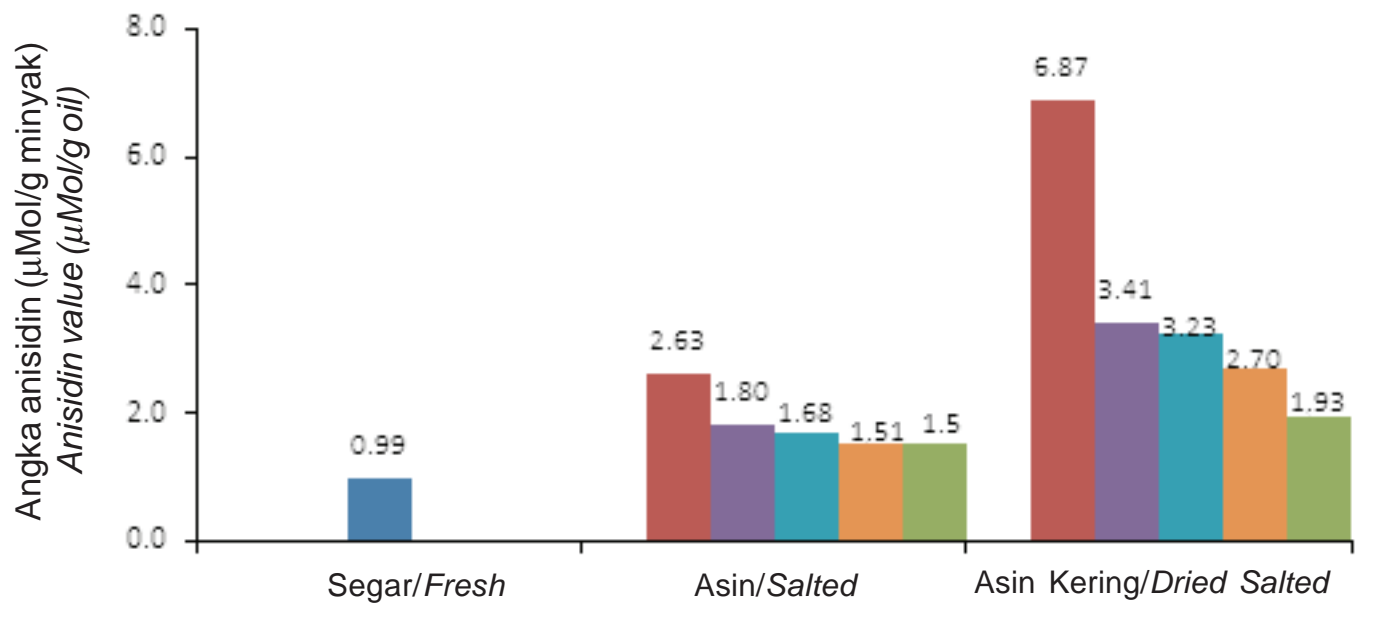

Jenis produk patin/Kind of patin products

Kontrol/Control
Ekstrak sirih/Betel extract : $5.0 \%$
Ekstrak sirih/Betel extract : $7.0 \%$

Ekstrak sirih/Betel extract : $4.0 \%$

Ekstrak sirih/Betelextract : $6.0 \%$

Gambar 2. Angka anisidin patin segar, patin asin, dan patin asin kering pada berbagai perlakuan penambahan ekstrak air daun sirih.

Figure 2. Anisidin value of fresh, salted and dried salted catfish with addition of various betel leaf water extract. 
pengeringan yang terlihat dari angka anisidin patin asin kering kontrol yang secara nyata lebih tinggi dibandingkan patin asin kontrol. Pada proses oksidasi selama pengeringan telah terjadi dekomposisi secara cepat pada hidroperoksida yang bersifat labil yang kemudian terdekomposisi lebih lanjut membentuk radikal bebas dan produk lain seperti aldehid yang reaktif terhadap $p$-methoxyaniline (anisidin) (Shahidi \& Zhong, 2009, Widjaja, et al., 2009b). Dengan demikian pengeringan secara nyata menaikkan angka Anisidin sebagaimana dinyatakan oleh Ortis et al. (2013) yang telah mengeringkan filet salmon (Salmo salar L) menggunakan convective dryer.

Perlakuan ekstrak daun sirih pada penelitian ini secara jelas menurunkan angka anisidin pada patin asin maupun patin asin kering dibandingkan kontrol. Konsentrasi sirih yang semakin tinggi menghasilkan angka anisidin yang semakin rendah pada patin asin kering, sedangkan pada patin asin tanpa pengeringan, perlakuan dengan berbagai konsentrasi ekstrak daun sirih tidak memperlihatkan signifikansi pada besaran angka anisidin.

Sirih mengandung gugus phenol seperti hydroxychavicol, chevibetol, allylpyrocatechol yang mempunyai aktivitas sebagai antioksidan (Arambewela et al., 2006b, Rathee et al., 2006, Dwivedi et al., 2014). Komponen phenol tersebut memiliki kemampuan mengurangi radikal bebas (scavenge free radicals) pada tahap inisiasi dan propagasi dari proses oksidasi (Pradhan et al., 2013).
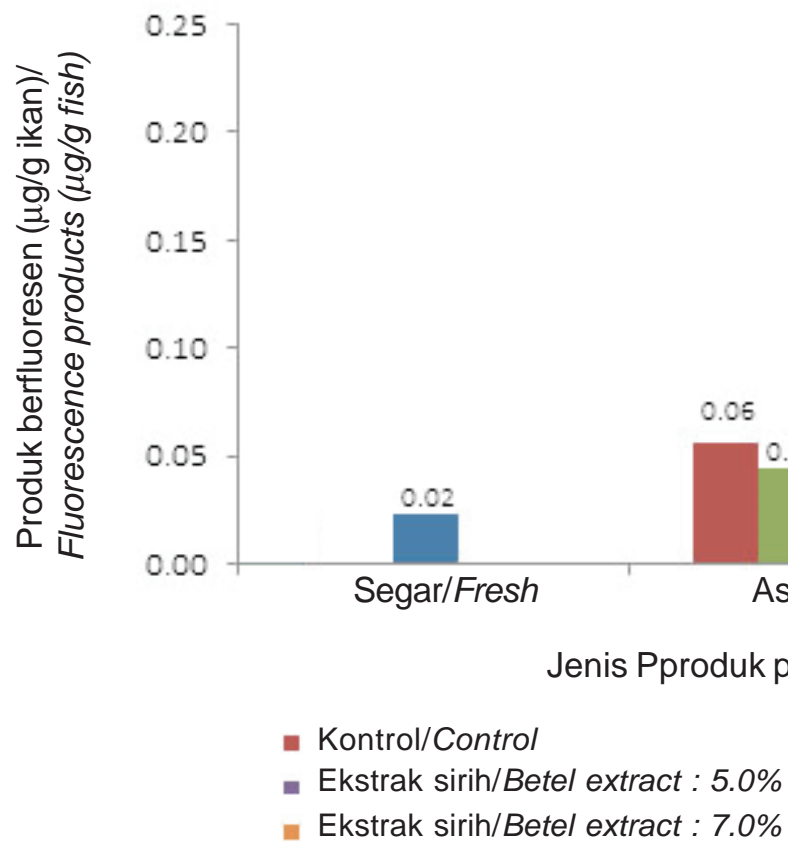

- Ekstrak sirih/Betel extract : $5.0 \%$
Kemampuan ini yang diduga kuat menjadi penyebab terjadinya penurunan produk oksidasi yang tercermin dari rendahnya nilai parameter oksidasi pada patin asin maupun patin asin kering seperti angka anisidin, TBA, dan lainnya.

\section{Produk Berfluoresen}

Deteksi produk berfluoresen sebagai hasil dari interaksi komponen sering dilakukan untuk menentukan kualitas khususnya untuk produk yang mengandung lemak tidak jenuh dan asam amino yang tinggi (Aubourg, 1998). Dinyatakan pula bahwa metoda analisis produk berfluoresen merupakan metoda yang mempunyai ketepatan tinggi dalam mendeteksi proses oksidasi pada produk pangan terutama ikan (Fletcher et al., 1973; Lubis, 1989; Ariyani, 1998; Aubourg, 2000; Shahidi \& Zhong, 2005; Sádecká \& Tóthová, 2007).

Berdasarkan hasil penelitian, diketahui bahwa angka produk berfluoresen lebih rendah secara nyata pada patin asin maupun patin asin kering dengan perlakuan ekstrak daun sirih dibanding kontrol (Gambar 3). Juga terlihat bahwa terjadi perbedaan angka produk berfluoresen patin asin dan patin asin kering yang cukup besar. Hal ini mencerminkan bahwa tingkat oksidasi pada patin asin kering lebih tinggi dibanding dengan tingkat oksidasi pada patin asin. Keterlibatan panas dan oksigen dari atmosfir pada saat proses pengeringan di bawah sinar matahari secara nyata meningkatkan proses oksidasi sebagaimana

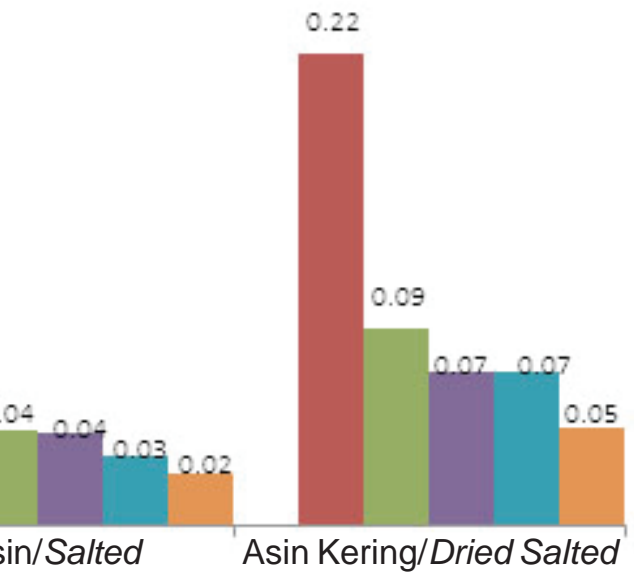

patin/Kind of patin products

- Ekstrak sirih/Betel extract : $4.0 \%$

- Ekstrak sirih/Betel extract : $6.0 \%$

Gambar 3. Produk berfluoresen patin segar, patin asin, dan patin asin kering pada berbagai perlakuan penambahan ekstrak air daun sirih.

Figure 3. $\quad$ Flurescenct products of fresh, salted and dried salted catfish with addition of various betel leaf water extract. 
dinyatakan oleh Pokorny et al. (2001), sedangkan oksidasi yang terjadi karena proses penggaraman hanya disebabkan oleh adanya pertukaran ion Fe oleh ion Na (Gheisari et al., 2010). Daging ikan pada umumnya mengandung ion Fe bebas dalam jumlah yang terbatas, $\mathrm{NaCl}$ akan menginterferensi ikatan antara ion Fe dengan protein sehingga ion Fe banyak dibebaskan dan berinteraksi dengan fraksi lemak yang memicu terjadinya peroksidasi (Gheisari et al., 2010). Hal ini mendukung pernyataan Hasegawa et al. (1992) bahwa produk berfluoresen mempunyai korelasi positif yang tinggi dengan jumlah oksigen terabsorbsi selama proses oksidasi pada ikan kering sedangkan Chotimarkorn et al. (2006) menyatakan bahwa produk berfluoresen berkorelasi positif dengan hidrokperoksida total pada ekstrak daging ikan.

Patin asin maupun patin asin kering dengan perendaman dalam ekstrak daun sirih pada penelitian ini memiliki nilai produk berfluoresen yang lebih rendah dibanding kontrol. Hal ini mengindikasikan bahwa ekstrak daun sirih mempunyai kemampuan untuk memperlambat pembentukan produk sekunder pada proses peroksidasi. Pada proses oksidasi, produk sekunder tersebut selanjutnya berikatan dengan protein, asam amino, peptide, maupun DNA membentuk produk berfluoresen (Shahidi \& Zhong, 2005; Azhar \& Nisa, 2006; Ortis et al., 2014). Lebih lanjut dinyatakan bahwa 2 molekul asam amino bereaksi dengan 1 molekul malonaldehid membentuk basa Schiff terkonjugasi, sedangkan reaksi malonaldehid dengan ribonuklease membentuk struktur 1-amino-3-iminopropene yang merupakan komponen berfluoresen (Azhar \& Nisa, 2006). Apabila dilihat dari efektivitasnya, ekstrak daun sirih dengan konsentrasi lebih tinggi menunjukkan efektivitas penghambatan proses oksidasi yang lebih tinggi yang tercermin dari rendahnya nilai produk berfluoresen pada ekstrak daun sirih 7\%, sebaliknya ekstrak daun sirih 4\% memberikan nilai produk berfluoresen paling tinggi dan tidak berbeda nyata dengan 5\%. Besarnya nilai produk berfluoresen ini bervariasi tergantung pada jenis ikan dan proses pengolahannya. Sardin asin kering setelah selesai proses pengeringan mempunyai nilai produk berfluoresen 0,2-0,3 $\mu \mathrm{g} / \mathrm{g}$ ikan (Lubis, 1990; Ariyani, 1998). Produk berfluoresen patin asin kering kontrol pada penelitian ini sebesar 0,22 $\mu \mathrm{g} / \mathrm{g}$ ikan, yang nilainya sama dengan kisaran nilai produk berfluoresen sardin asin kering pada penelitian Ariyani (1998) dan Lubis (1990), sementara pada patin asin kering dengan perlakuan ekstrak daun sirih jauh lebih rendah yakni berkisar 0,046-0,091 $\mu \mathrm{g} / \mathrm{g}$ ikan. Pada patin asin tanpa pengeringan, nilai produk berfluoresen mengalami penurunan dengan adanya perlakuan ekstrak daun sirih, $(0,024-0,044 \mu \mathrm{g} / \mathrm{g}$ ikan) dan nilai tersebut masih lebih rendah dibanding produk berfluoresen pada patin asin setelah pengeringan. Kandungan phenol yaitu hydroxychavicol, chevibetol, allylpyrocatechol pada ekstrak daun sirih (Arambewela et al., 2006b; Rathee et al., 2006; Dwivedi et al., 2014) diduga kuat merupakan komponen yang bertanggung jawab pada penurunan angka produk berfluoresen sebagai akibat penghambatan proses oksidasi selama pengolahan patin asin kering dengan perlakuan ekstrak daun sirih.

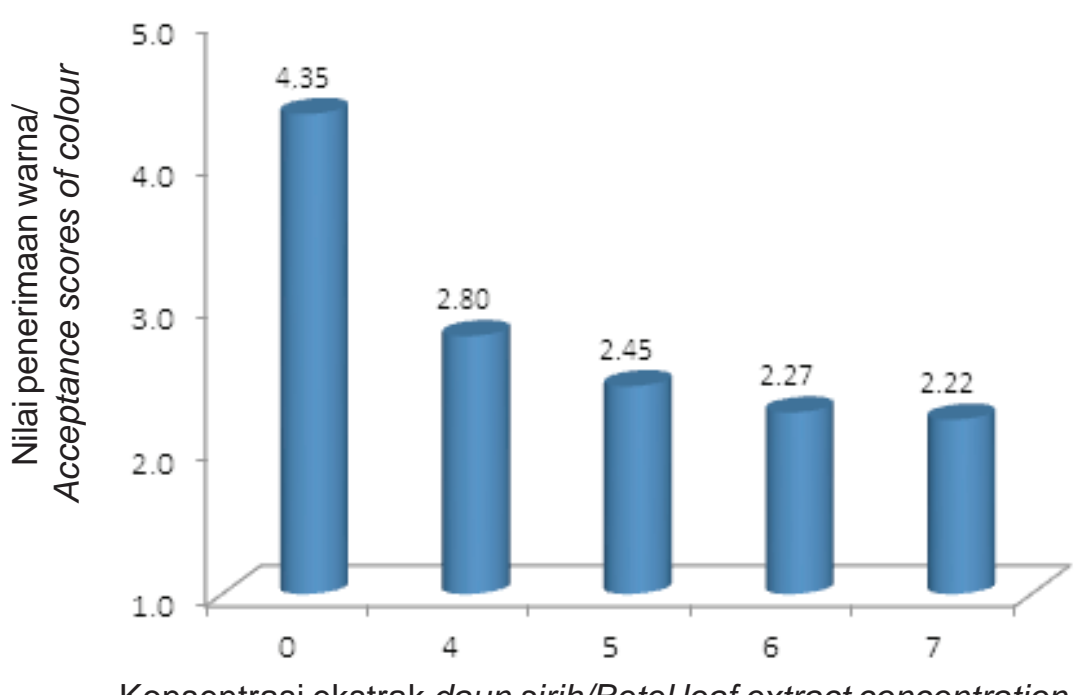

Gambar 4. Nilai penerimaan warna patin asin kering mentah pada berbagai perlakuan penambahan ekstrak air sirih.

Figure 4. Acceptance scores of colour of raw dried salted catfish with addition of various betel leaf extract. 


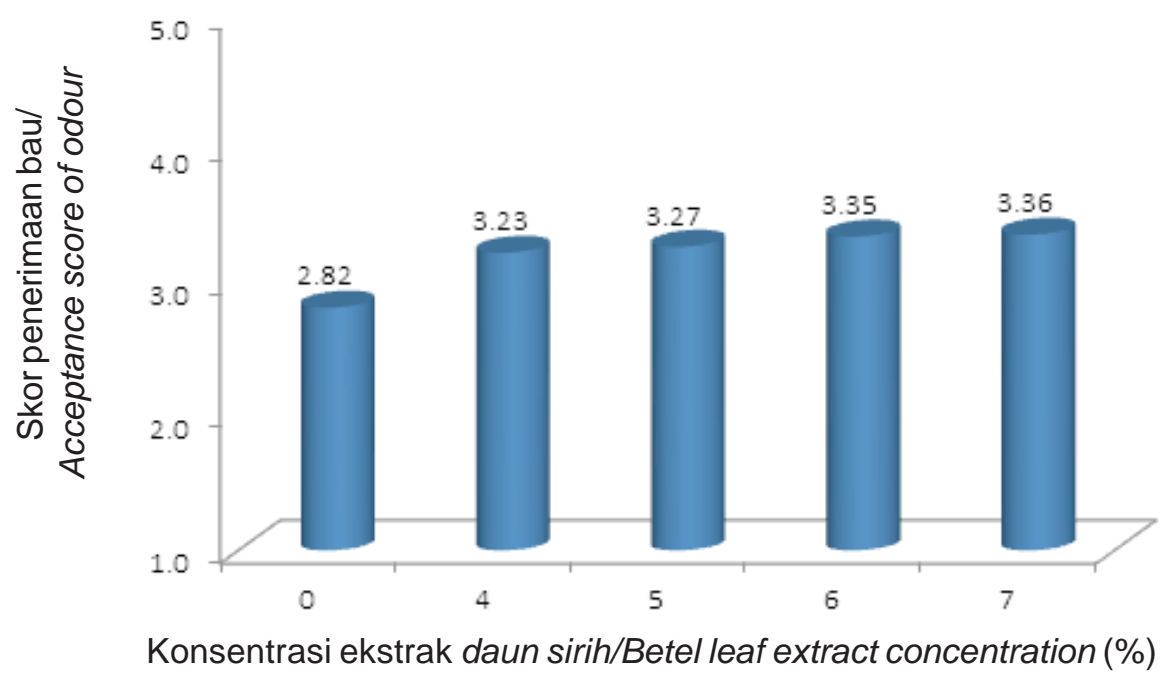

Gambar 5. Nilai penerimaan bau patin asin kering mentah pada berbagai perlakuan penambahan ekstrak air daun sirih.

Figure 5. Acceptance scores of odour of raw dried salted catfish with addition of various betel leaf water extract.

\section{Uji Sensori}

\section{Uji sensori patin asin mentah}

Hasil uji pembedaan atribut warna dan bau dapat dilihat pada Gambar 4 dan 5. Patin asin kering kontrol mempunyai warna kuning kecoklatan, sedangkan patin asin kering dengan perlakuan ekstrak daun sirih memiliki warna lebih gelap yakni coklat muda-coklat tua sehingga panelis memberikan nilai penerimaan terhadap warna patin asin kering dengan perlakuan ekstrak daun sirih lebih rendah $(2,22-2,80)$ secara nyata dibanding patin asin kering kontrol $(4,35)$ dan semakin tinggi konsentrasi ekstrak daun sirih yang ditambahkan semakin rendah nilai penerimaan terhadap warna patin asin kering (Gambar 4). Di antara semua perlakuan, penambahan ekstrak daun sirih pada konsentrasi 4\% (b/v) menghasilkan nilai penerimaan warna tertinggi (2,80 dengan kriteria coklat muda), sedangkan nilai penerimaan terendah terdapat pada perlakuan dengan konsentrasi ektrak daun sirih $7 \%$ (2,22 dengan kriteria coklat tua). Minyak atsiri yang terdapat pada extrak daun sirih mengandung phenols yang mayoritas berupa chavibetol (4-allyl-2hydroxy-1-methoxy benzene) dan terpene yang berwarna kuning terang sampai coklat tua yang beraroma dan berasa tajam/pungent (Irani, 2005; Rai et al., 2005; Dwivedi et al., 2014).

Senyawa polifenol tersebut diduga sebagai penyebab terjadinya perubahan warna patin asin kering dengan perlakuan ekstrak daun sirih. Pada proses oksidasi selanjutnya komponen fenolik ini akan berkondensasi menghasilkan komponen dengan berat molekul tinggi yang berwarna coklat (Haard \& Chism, 1994).

Pada penelitian ini, aroma/bau patin asin kering mentah tanpa penambahan ekstrak daun sirih (kontrol) berkisar tengik-agak tengik dengan nilai 2,82, sedangkan patin asin kering dengan perlakuan ekstrak daun sirih berkisar antara agak tengik sampai tidak tengik dengan kisaran nilai 3,23-3,36 sehingga panelis memberikan nilai penerimaan terhadap atribut bau lebih tinggi pada patin asin kering dengan perlakuan ekstrak daun sirih (Gambar 5). Penambahan ekstrak daun sirih pada konsentrasi 4-7\% memberikan nilai penerimaan bau yang lebih tinggi dari kontrol dan tidak terdapat perbedaan secara nyata di antara perlakuan. Selain karena adanya daya hambat ekstrak daun sirih terhadap proses oksidasi, berkurangnya bau tengik pada patin asin kering mentah dengan perlakuan ekstrak daun sirih, kemungkinan dapat juga disebabkan terjadinya penutupan ('masking') bau tengik oleh bau tajam daun sirih, meskipun dalam lembar penilaian, panelis tidak diminta untuk menilai bau lain selain tengik. Namun demikian, apabila dikorelasikan dengan hasil penilaian secara kimiawi, pengurangan bau tengik pada patin asin kering dengan perlakuan ekstrak daun sirih sejalan dengan hasil analisis TBA, yang memperlihatkan bahwa angka TBA patin asin kering kontrol sebesar 15,10 $\mu \mathrm{Mol} / \mathrm{kg}$ daging ikan yang berarti telah tengik karena telah melebihi batas angka ketengikan $10 \mu \mathrm{Mol} / \mathrm{kg}$ daging ikan (Ke \& Ackman, 1976), sedangkan patin asin kering dengan perlakuan ekstrak daun sirih belum tengik dengan besaran angka TBA 4,74-6,42 $\mu \mathrm{Mol} /$ $\mathrm{kg}$ daging ikan. Fenomena ini mengindikasikan bahwa 
penambahan ekstrak daun sirih secara nyata dapat menekan proses oksidasi yang menimbulkan bau tengik.

\section{Uji sensori patin asin matang}

Penilaian terhadap atribut bau patin asin kering matang ini ditujukan untuk mengkonfirmasi apakah bau tengik hasil penilaian pada patin asin matang masih sama dengan nilai bau pada patin asin kering mentah.

Hasil pengujian menunjukkan bahwa semua patin asin kering matang dengan perlakuan ekstrak daun sirih maupun kontrol memiliki nilai penerimaan yang tidak berbeda secara nyata dengan kisaran nilai 3,333,56 dengan deskripsi antara agak tengik-tidak tengik (Gambar 6). Apabila dibandingkan dengan nilai bau pada patin asin kering mentah, intensitas ketengikan pada patin asin kering matang lebih rendah. Perbedaan penilaian ini kemungkinan disebabkan oleh hilangnya sebagian aroma tengik pada saat pemanggangan dengan microwave untuk patin asin kering matang, sehingga ketengikan terdeteksi lebih intens pada patin asin kering mentah dari pada patin asin kering matang.

Selain bau, atribut rasa patin asin kering matang pada penelitian ini juga diamati untuk mengetahui sejauh mana pengaruh rasa daun sirih pada patin asin kering matang.

Berdasarkan Gambar 7, panelis memberikan nilai rasa patin asin kontrol 3,90 yang berarti tidak getir, sedangkan patin asin dengan perlakuan ekstrak daun sirih memiliki kisaran nilai 2,77-3,26 dengan deskripsi getir -sedikit getir. Di antara semua perlakuan, rasa getir dengan nilai yang paling rendah dimiliki oleh patin asin dengan perlakuan ekstrak daun sirih konsentrasi paling tinggi (7\%), sebaliknya patin asin dengan penambahan ekstrak daun sirih dengan konsentrasi paling rendah (4\%) memperoleh nilai penerimaan tertinggi. Ekstrak daun sirih mempunyai rasa spesifik 'pungent' karena kandungan chavibitol yang merupakan isomer dari eugenol dan merupakan komponen aromatik penyebab rasa tajam 'pungent' seperti asap/tar (Dwivedi \& Tripathi, 2014). Pada proses oksidasi, komponen fenolik yang terdegradasi menjadi quinon akan bereaksi dengan protein yang juga mengakibatkan rasa getir (Lindsay, 1994).

\section{Penentuan Perlakuan Terpilih}

Berdasarkan hasil analisis sensori secara umum, diketahui bahwa dibanding kontrol, perlakuan penambahan ekstrak daun sirih selama proses penggaraman akan menurunkan nilai penerimaan patin asin kering untuk atribut warna karena menjadi lebih coklat maupun atribut rasa karena terdeteksinya rasa getir, sedangkan untuk atribut bau, penambahan ekstrak daun sirih justru meningkatkan nilai penerimaan karena berkurangnya bau tengik. Penurunan nilai atribut warna dan rasa paling besar terjadi pada perlakuan ekstrak daun sirih dengan konsentrasi tinggi (7\%) dan penurunan terkecil terjadi pada perlakuan ekstrak daun sirih konsentrasi terendah (4\%).

Ditinjau dari aspek kimiawi, semua nilai parameter oksidasi (TBA, angka anisidin serta produk berfluoresen) pada patin asin dengan perlakuan

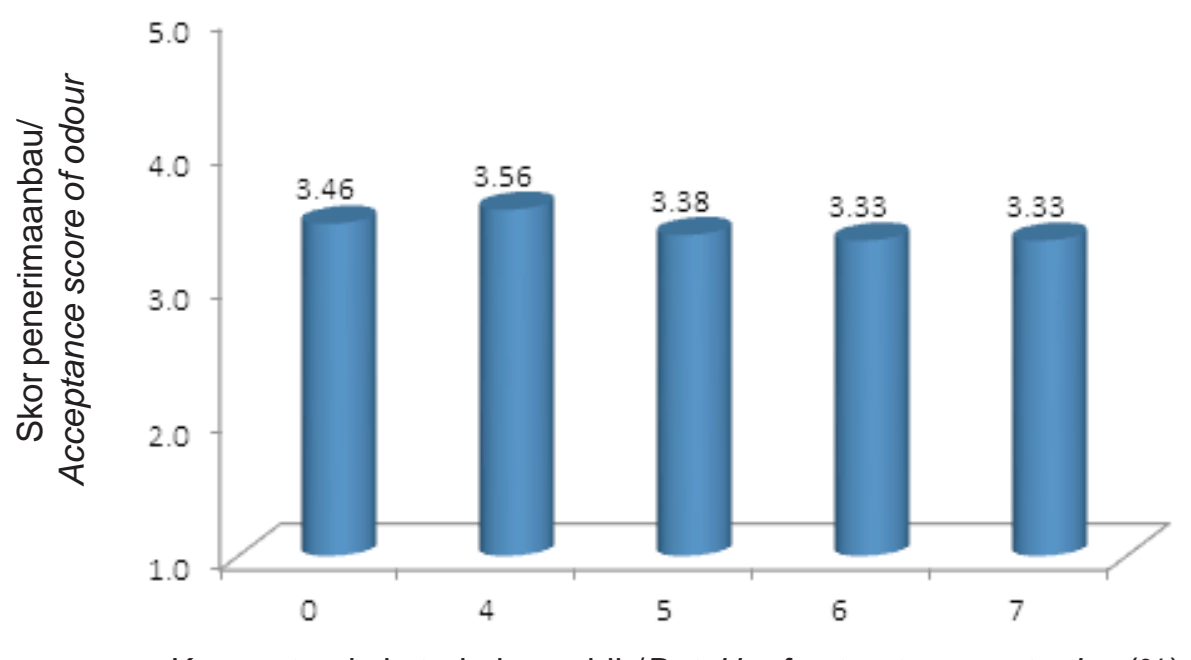

Konsentrasi ekstrak daun sirih/Betel leaf extract concentration (\%)

Gambar 6. Nilai penerimaan bau patin asin kering matang pada berbagai perlakuan penambahan ekstrak air daun sirih.

Figure 6. Acceptance scores of odour of cooked dried salted catfish with addition of various betel leaf water extract. 


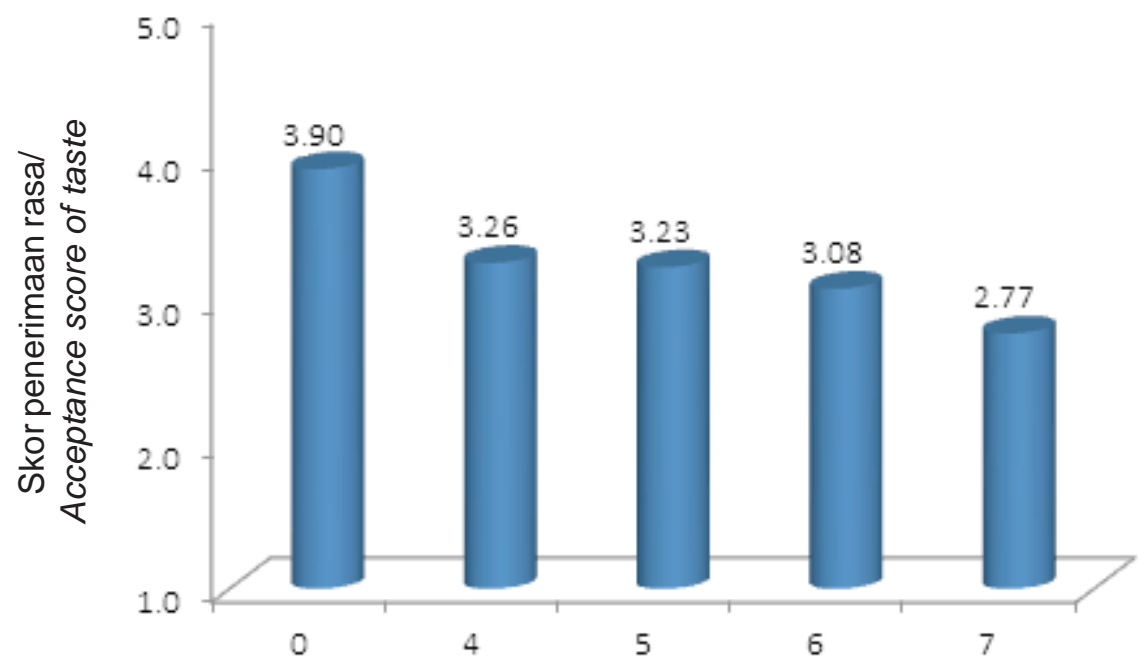

Konsentrasi ekstrak daun sirih/Betel leaf extract concentration (\%)

Gambar 7. Nilai penerimaan rasa patin asin kering matang pada berbagai perlakuan penambahan ekstrak air daun sirih.

Figure 7. Acceptance scores of taste of cooked dried salted catfish with addition of various betel leaf water extract.

penambahan ekstrak daun sirih memperlihatkan penghambatan proses oksidasi secara nyata dibanding kontrol. Penghambatan semakin tinggi seiring dengan peningkatan ekstrak daun sirih yang ditambahkan, yang berarti bahwa perlakuan penambahan ekstrak daun sirih konsentrasi $7 \%$ memberikan tingkat penghambatan yang tertinggi, sementara konsentrasi ekstrak daun sirih $4 \%$ memberikan tingkat penghambatan yang terendah.

Dalam menentukan perlakuan terpilih harus dipertimbangkan aspek kimiawi maupun sensori, yakni didasarkan pada efektifitas ekstrak tersebut tanpa menghilangkan karakteristik dasar produk akhir dan masih diterima secara sensori. Berdasarkan hasil pengamatan secara kimiawi, perlakuan penambahan ekstrak daun sirih 4\% merupakan perlakuan yang masih mampu menekan perkembangan oksidasi patin asin kering meskipun penghambatannya lebih rendah dibanding perlakuan lain, sedangkan dari hasil analisis secara sensori, perlakuan penambahan ekstrak daun sirih 4\% menghasilkan nilai penerimaan yang paling tinggi di antara perlakuan lain. Oleh karena itu, perlakuan terpilih dari hasil penelitian ini adalah perlakuan penambahan ekstrak daun sirih $4 \%$.

\section{KESIMPULAN DAN SARAN}

\section{Kesimpulan}

Ekstrak air daun sirih memiliki aktivitas antioksidan lebih tinggi dibandingkan BHT. Penambahan ekstrak air daun sirih dengan konsentrasi 4-7\% (b/v) selama penggaraman dalam proses pembuatan patin asin mampu menghambat proses oksidasi lemak patin asin dan patin asin kering yang tercermin dari rendahnya angka TBA, angka anisidin, dan produk berfluoresen dibanding kontrol.

Didasarkan pada pertimbangan hasil pengujian secara kimiawi dan penilaian secara sensori, perlakuan terpilih dari penelitian ini adalah kelompok perlakuan penambahan ekstrak daun sirih 4\% yang menghasilkan patin asin kering dengan angka TBA $6,42 \mu \mathrm{Mol} \mathrm{MDA} / \mathrm{kg}$ (kontrol 15,10 $\mu \mathrm{Mol} \mathrm{MDA} / \mathrm{kg}$ ), angka anisidin $3,41 \mu \mathrm{Mol} / \mathrm{g}$ minyak (kontrol 6,87 $\mu \mathrm{Mol} /$ g minyak), dan produk berfluoresen 0,091 $\mu \mathrm{g} / \mathrm{g}$ ikan (kontrol 0,219 $\mu \mathrm{g} / \mathrm{g}$ ikan). Karakteristik sensori patin asin dengan perlakuan terpilih berwarna coklat muda, berbau tidak tengik, dan berasa sedikit getir.

\section{Saran}

Diperlukan kajian dan penelitian lanjut untuk mengurangi/menghilangkan bau tajam dan rasa getir yang ditimbulkan oleh daun sirih.

\section{DAFTAR PUSTAKA}

Abrahim, N.N., Kanthimathi, M.S., \& Abdul-Aziz, A. (2012). Piper betle shows antioxidant activities, inhibits MCF7 cell proliferation and increases activities of catalase and superoxide dismutase. BMC Complementary and Alternative Medicine, 12: 220 Page 7 of 11

Alam, Md.B., Akter, F., Parvin, N., Pia, R.S., Akter, S., Chowdhury, J., Sifath-E-Jahan, K., \& Haque, Md.E. 
(2012). Antioxidant, analgesic and anti-inflammatory activities of the methanolic extract of Piper betle leaves. Avicenna Journal of Phytomedicine, 27: 114.

AOCS. (1997). Official and Tentative Methods of the American Oil Chemists Society. $3^{\text {rd }}$. AOCS. Chicago.

Arambewela, L. \& Alagiyawanna, S. (2006a). Piper betel. In Warnasuriya, D. (ed.). Sri Lankan medicinal plant. Monographs and analysis (42 p). Vol-9. Ceylon Institute of Scientific and Industrial Research. Colombo, National Science Foundation.

Arambewela, L., Arawwawala, M., \& Rajapaksa, D. (2006b). Piper betel : a Potential natural antioxidant. International Journal of Food Science, 41, 10-14.

Arambewela, L.S.R., Arawwawala, L.D.A.M, Kumaratunga, K.G., Dissanayake, D.S., Ratnasooriya, W.D., \& Kumarasingha, S.P. (2011). Investigations on Piper betle grown in Sri Lanka. Review Article, 5(10), 159-163.

Arawwawala, L.D.A.M., Hewageegana, H.G.S.P., Lakshmi Sriyani Rajapaksha Arambewela, L.S.R., \& Ariyawansa, H.S. (2011b). Standardization of spraydried powder of Piper betle hot water extract. Pharmacogn Mag., 7(26), 157-160

Ariyani, F. (1998). Effect of raw material quality on lipids and flavour characteristics of dried salted sardines. Thesis. Department of Food Science and Technology. Faculty of Applied Science. The University of New South Wales.

Ariyani, F., Amin, I., Fardiaz, D., \& Budiyanto, S. 2008. Aplikasi ekstrak daun sirih (Piper Betle Linn) dalam menghambat oksidasi lemak jambal patin (Pangasius hypophthalmus). Jurnal Pascapanen dan Bioteknol. Kelautan \& Perikanan, 3(2), 157-169.

Aubourg, S.P. (2000). Assessment of antioxidant effectivenes on thermally treated marine lipids by fluorescence detection. Eur Food Res Technol., 211, 310-31.

Azhar, K.F. \& Nisa, K. (2006). Lipids and their oxidation in seafood. J. Chem. Soc. Pak., 28(3): 298-305.

Badan Standar Nasional. 2006. Penentuan kadar lemak total pada produk perikanan. SNI 01-2354.3-2006. BSN. Jakarta.

Bligh, E.G. \& Dyer, W.J. (1959) A rapid method of total lipid extraction and purification. Can. J. Biochem. Physiol., 37(8), 911-917.

Ceballos, M.J. (2012). Effect of protein and lipid oxidation in the changes of color in salted and dried herring and klippfish. Thesis. Norwegian University of Science and Technology. Department of Biotechnology.

Chotimarkorn, C., Ohshim, T., \& Ushio, H. (2006). Fluorescent image analysis of lipid hydroperoxides in fish muscle with 3-perylene diphenylphosphine. Lipid, 41(3), 295-300.

Choundhary, D. \& Kale, R.K. (2002). Antioxidant and nontoxic properties of Piper betel leaf extract: in vitro and in vivo studies. Phytotherapy Research, 16, 461466

Dasgupta, N. \& Bratati De. (2004). Antioxidant activity Piper betle L. leaf extract in vitro. Food Chemistry., 88(2), 219-224.
Devatkal, S.K., Narsaiah, K. \& Borah, A. (2011). The effect of salt, extract of kinnow and pomegranate fruit byproducts on colour and oxidative stability of raw chicken patties during refrigerated storage. J Food Sci. Technol., 48(4): 472-477.

Ditjen Perikanan Tangkap. (2013). Produksi ikan olahan Indonesia tahun 2012 dalam ton. Statistik Perikanan Tangkap Indonesia.13(1).

Domiszewski, Z., Bienkiewicz, G., \& Dominika, P.I. (2011). Effects of different heat treatments on lipid quality of striped catfish (Pangasius hypophthalmus). Sci. Pol., Technol. Aliment., 10(3), 359-373

Dwivedi, V. \& Tripathi, S. (2014). Review study on potential activity of Piper betle. Journal of Pharmacognosy and Phytochemistry, 3(4), 93-98

Fletcher, B.L., Dillard, C.J. \& Tappel, A.L. (1973). Measurement of fluorescent Lipid peroxidation products in biological systems and tissues. Analytical Biochemistry., 52, 1-9

Gheisari, H.R., Møller, J.K.S., Adams, C.E., \& Skibsted, L.H. (2010). Sodium chloride or heme protein induced lipid oxidationin raw, minced chicken meat and beef. Czech J. Food Sci., 28(5): 364-375.

Haard, N. \& Chism, G.W. (1994). Characteristics of edible plant tissues. In Fennema, O.R. (ed.). Food Chemistry (pp. 943-1001). $3^{\text {rd }}$ Edition. New York. Marcel Dekker Inc.

Haryati, S. (2006). Optimalisasi penggunaan bawang putih sebagai pengawet alami dalam pengolahan ikan asin jambal roti. Tesis. Program Pascasarjana, Institut Pertanian Bogor, Bogor.

Hasegawa, K., Endo, Y., \& Fujimoto, K. (1992). Oxidative deterioration in dried fish model systems assessed by solid sample fluorescence spectrophotometry. J. Food Sci., 57(5), 1123-1126.

Heruwati, E.S., Ariyani, F., Indriati, N., Yenni, Y., Riyanto R., \& Kusmarwati, A. (2007). Riset Kajian Mutu dan Keamanan Produk Perikanan Akibat Kesalahan Penanganan dan Pengolahan. Laporan Teknis. Balai Besar Riset Pengolahan Produk dan Bioteknologi Kelautan dan Perikanan. Badan Litbang Kelautan dan Perikanan. $62 \mathrm{p}$.

Hwang, K.T., Kim, J.E., Kang, S.G., Jung, S.T., Park, H.J., Weller, C.L. 2004. Fatty acid composition and oxidation of lipids in korean catfish. J. Am. Oil Chem. Soc., 81(2), 123-127.

Irani, F. (2005). An encounter with ayurveda aromatherapy. Aroma therapy journal. p. 32. Retrieved from WWW.NAHA.ORG.

Jaiswal, S.G., Patel,M., Saxena, D.K. \& Naik, S.N. (2014). Antioxidant properties of Piper betel (L) leaf extracts from six different. Journal of Bioresource Engineering and Technology, 2(2), 12-20.

Ke, P.J. \& Ackman, R.G. (1976). Metal-catalysed oxidation in mackerel skin and meat lipids. J. Am. Oil Chem. Soc., 53(10), 636-640.

Kolodziejska, I., Niecikowska, C., Sikorski, Z.E., \& Kolkowska, A. (2004). Lipid oxidation and lysine availability in Atlantic mackerel hot smoked in mild conditions. Bulletin of the Sea Fisheries Institute., 1 (16), 15-27. 
Legowo, A.M., Soepardi, Miranda, R., Anisa, I.S.N., \& Rohidayah, Y. (2002). Pengaruh perendaman daging pra kyuring dalam jus daun sirih terhadap ketengikan dan sifat organoleptik dendeng sapi selama penyimpanan. Jurnal Teknol. dan Industri Pangan. 13(1), 64-69.

Lim, P.H. \& Mohamed, S. (1999). Antioxidative and antimycotic effects of turmeric, lemon-grass, betel leaves, clove, black pepper leaves and garcinia atriviridis on butter cakes. J. Sci. Fd. and Agric. 79, 1817-1822.

Lindsay, R.C. (1994). Flavors. In Fennema, O.R. (ed.). Food Chemistry (pp. 723-765). $3^{\text {rd }}$ Edition. New York. Marcel Dekker Inc. .

Lubis, Z. (1989). Studies on the stability of lipids in dried salted sardines. Thesis. Department of Food Science and Technology, School of Applied Bioscience, Faculty of Applied Science. The University of New South Wales.

Lubis, Z. \& Buckle, K.A. (1990). Rancidity and lipid oxidation of dried-salted sardines. Int. J. Food Sci. Technol., 25, 295-303.

Meilgaard, M.G.V., Civille \& Carr, B.T. (1999). Sensory evaluation technique. 3rd Edition. CRC Press. Boca Raton-London-New York-Washington, D.C.

Nasran, S., Murtini, J.T., Rahayu, S., Mahyudin, Hanafi, Sudrajat, Y., Gunawan, B., \& Maryadi. (1995). Laporan teknis penelitian teknologi proses fermentasi dan pengasapan hasil perikanan untuk pengembangan agroindustri pedesaan. Balai Penelitian Perikanan Laut, Pusat Penelitian dan Pengembangan Perikanan, Jakarta.

Ortiz, J, Lemus-Mondaca, R., Vega-Galvez, A., Ah-Hen, K., Puente-Diaz, L., Zura-Bravo, L., \& Aubourg, S.P. (2013). Influence of air-drying temperature on drying kinetics, colour, firmness and biochemical characteristics of Atlantic salmon (Salmo salar L.) fillets. Food Chemistry, 139, 162-169.

Ortiz, J., Vivanco, J, P., \& Aubourg, S.P. (2014). Lipid and sensory quality of canned Atlantic salmon (Salmo salar): Effect of the use of different seaweed extracts as covering liquids. Eur. J. Lipid Sci. Technol., 116, 596-605.

O'Sullivan, C.M., Lynch, A.M, Lynch, P.B., Buckley, D.J. \& Kerry, J.P. (2004). Use of antioxidants in chicken nuggets manufactured with and without the use of salt and/or sodium tripolyphosphate: Effects on product quality and shelf-life stability. International Journal of Poultry Science, 3(5), 345-353.

Pin, K.Y., Chuah, A.L., Rashih, A.A., Mazura, M.P., Fadzureena, J., Vimala, S., \& Rasadah, M.A. (2010). Antioxidant and anti-inflammatory activities of extracts of betel leaves (Piper betle) from solvents with different polarities. Journal of Tropical Forest Science, 22(4), 448-455.

Pokorny, J., Yanishlieva, N., \& Gordon, M. (2001). Antioxidants in food. Pratical Application. Woodhead Publishing Limited. Cambridge England
Pradhan, D., Suri, K.A., Pradhan, D.K., \& Biswasroy, P. (2013). Golden heart of the nature: Piper betle L. Journal of Pharmacognosy and Phytochemistry, 1(6), 147-167.

Ramanathan, L. \& Das, N.P. (1992). Studies on the control of lipid oxidation in ground fish by some polyphenolic natural products. J. Agric. Food Chem., 40(1), 17-21.

Rai, S., Mal, M., Wahile, A., \& Mukherjee, P.K. (2005). Therapeutic potentials and untoward effects of Piper betle and its quid. A Riview. Oriental Pharmacy and Experimental Medicine, 5(4), 272-282

Rao, B.Y.K. \& Bandyopadhyay C. (1983). Lipid composition of salted-dried Indian mackerel (Rastrelliger kanagurta). J. Food Sci Technol., 20, 6264.

Rathee, J.S., Patro, B.S., Mula, S., Gamre, S., \& Chattopadhyay, S. (2006). Antioxidant activity of piper betel leaf extract and its constituents. J. Agric Food Chem., 54, 9046-9054.

Sádecká, J. \& Tóthová, J. (2007). Fluorescence Spectroscopy and Chemometrics in the Food Classification-a Review. Czech J. Food Sci., 25(4), 159-173.

Sanger, G. (2010). Oksidasi lemak ikan tongkol (Auxis thazard) asap yang direndam dalam larutan ekstrak daun sirih. Pacific Journal. 2(5), 870-873.

Shah, G.A, Islam, T., Sharma, E., Telang, S., \& Malla, B.A. (2013). Assessment of preliminary phytochemical screening and anti-oxidant potential of different extracts of Piper betle L. leaves. Int. J. Pharm. Sci. Rev. Res., 20(1), 189-192.

Shahidi, F. \& Zhong, Y. (2005). Lipid Oxidation Measurement Methods. In Shahidi, F. (ed.). Bailey's industrial oil and fat products (pp. 357-385). John Wiley \& Sons, Inc.

Sugiastuti, S. (2002). Kajian aktivitas antibakteri dan antioksidan ekstrak daun sirih (Piper betle L.) pada daging giling. Tesis. Program Pascasarjana. Institut Pertanian Bogor.

Wendy Voon, W. Y., Ghali, N. A., Rukayadi, Y., \& Meor Hussin, A.S. (2014). Application of betel leaves (Piper betle L.) extract for preservation of homemade chili bo. International Food Research Journal, 21(6), 2399-2403

Widjaja, W.P., Abdulamir, A.S., Saari, N., Abu Bakar, F., \& Ishak, Z. (2009a). Fatty acids profile of tropical bagridae catfish (Mystus nemurus) During Storage. American Journal of Food Technology, 4, 90-95.

Widjaja, W.P., Abdulamir, A.S., Abu Bakar, F., Saari, N., Ishak, Z. \& Hamid, A.A. (2009b). Lipid quality deteroriation of bagridae catfish (Mystus nemurus) during storage Research Journal of Biological Sciences, 4(4), 525-530.

Zanardi. (2014). Use of Added Oxidants in Food Processing. In Bartosz, G. (ed.). Food oxidants and antioxidants: Chemical, biological, and functional Properties (pp. 137-15). Boca Raton. CRC Press. 


\section{LAMPIRAN 1/ APPENDIX 1}

\section{UJI PEMBEDAAN WARNAI \\ COLOUR DIFFERENCE ASSESMENT}

Nama panelis/Panelists name

Tanggal pengujian/Date of assessment:

Jenis Sampel/Kind os sample

: Patin asin kering mentah/ Raw dried salted catfish

Instruksi/Instruction :

Dihadapan saudara terdapat lima sampel berkode. Amatilah dan nilailah warna sampel tersebut berdasarkan nilai sebagai berikut :

In front of you, there are 5 coded samples. Please observe and give scores for the colour of samples based on scores belows :

1 : Coklat kehitaman/Blackish brown

2 : Coklat tua/Dark brown

3: Coklat muda/Light brown

4: Kuning kecoklatan/Brownish yellow

5: Kuning muda/Light yellow

\begin{tabular}{|l|l|}
\hline KODE SAMPELISAMPLE CODE & NILAI/SCORES \\
\hline & \\
\hline & \\
\hline & \\
\hline & \\
\hline & \\
\hline
\end{tabular}

Komentar/Comment : 
LAMPIRAN 2IAPPENDIX 2.

\section{UJI PEMBEDAAN BAUI}

\section{AROMA DIFFERENCE ASSESMENT}

Nama panelis/Panelists name

Tanggal pengujian/Date of assessment :

Jenis Sampel/ Kind os sample

: Patin asin kering mentah/matang/Raw/Cooked Dried salted Catfish

Instruksi/Instruction :

Dihadapan saudara terdapat lima sampel berkode. Amatilah dan nilailah aroma/bau sampel tersebut berdasarkan nilai sebagai berikut :

In front of you, there are 5 coded samples. Please observe and give scores for the aroma/odour of samples based on scores belows:

1 : Sangat tengik/Very rancid

2 : Tengik/Rancid

3 : Agak Tengik/Slightly rancid

4 : Tidak Tengik/Not rancid

5 : Spesifik patin asin kering/Dried salted catfish characteristics

\begin{tabular}{|l|l|}
\hline KODE SAMPELISAMPLE CODE & NILAI/SCORES \\
\hline & \\
\hline & \\
\hline & \\
\hline & \\
\hline & \\
\hline
\end{tabular}

Komentar/Comment : 
LAMPIRAN 3IAPPENDIX 3.

UJI PEMBEDAAN RASAI

TASTE DIFFERENCE ASSESMENT

Nama panelis/Panelists name

Tanggal pengujian/Date of assessment :

Jenis Sampel/ Kind os sample

: Patin asin kering matang/Cooked Dried salted Catfish

Instruksi/Instruction :

Dihadapan saudara terdapat lima sampel berkode. Amatilah dan nilailah rasa sampel tersebut berdasarkan nilai sebagai berikut :

In front of you, there are 5 coded samples. Please observe and give scores for the taste of samples based on scores belows:

1 : Sangat getir/Very bitter

2 : Getir/Bitter

3: Sedikit getir/Slightly bitter

4 : Tidak getir/Not bitter

5 : Spesifik patin asin kering/Dried salted catfish characteristics

\begin{tabular}{|l|l|}
\hline KODE SAMPELISAMPLE CODE & NILAI/SCORES \\
\hline & \\
\hline & \\
\hline & \\
\hline & \\
\hline & \\
\hline
\end{tabular}

Komentar/Comment : 
